\title{
Evaluación del dispositivo Pavement Quality Indicator (PQI) en la determinación de la densidad in situ de mezclas fabricadas con emulsión bituminosa
}

\section{Evaluation of the Pavement Quality Indicator (PQI) for the on-site density measurement of asphalt emulsion mixes}

\author{
M. J. Martínez-Echevarría(*), E. Tejeda(**), M. C. Rubio(*), F. Moreno(*)
}

Recepción/Received: 1-VI-11

Aceptación/Accepted: 16-I-12

\section{RESUMEN}

El equipo Pavement Quality Indicator es un dispositivo para la determinación de densidad in situ en pavimentos asfálticos sin extracción de testigos. Las experiencias con este equipo en mezclas bituminosas en caliente, recogidas en diferentes fuentes bibliográficas, muestran que las densidades medidas in situ con el PQI son muy similares a las obtenidas mediante la extracción de testigos. En este artículo se expone la primera etapa de un proyecto de investigación que tiene por objeto analizar los resultados de mediciones efectuadas con PQI en mezclas bituminosas donde se utiliza emulsión asfáltica como ligante. Se comprueba la variabilidad de la densidad obtenida con el equipo para este tipo de mezclas, y se comparan los resultados con otros métodos de medida de densidad in situ.

Palabras clave: densidad in situ; mezclas en frío con emulsiones; mezclas templadas; Indicador de calidad del pavimento.

\section{SUMMARY}

The Pavement Quality Indicator (PQI) is a non-nuclear gauge used for the on-site density measurement of asphalt pavements without the need to extract core samples. Previous studies of hot asphalt mixes found that $P Q I$ density readings were very similar to laboratory density measurements of pavement cores. This paper describes the first stage of a research project whose objective is to analyze PQI density measurements of mixes manufactured with an asphalt emulsion binder. The $P Q I$ density variability for such mixes was verified and compared with the results obtained with other on-site methods for measuring pavement density.

Keywords: on-site density; cold asphalt emulsion mix; warm asphalt mix; pavement quality indicator.

\footnotetext{
(*) Universidad de Granada (Granada, España).
}

(**) Universidad de La Habana (La Habana, Cuba). 


\section{INTRODUCCIÓN}

La calidad de las mezclas bituminosas (en adelante, m.b.), desde el punto de vista estructural, está condicionada por dos factores principales: su diseño y la densidad alcanzada durante la ejecución (1). Disponer de los resultados de densidad en el momento de su ejecución es importante para poder corregir la compactación en caso de no estar obteniendo los resultados esperados. Los métodos habituales de medida de densidad de las m.b. son: (i) la extracción de testigos y determinación de su densidad en laboratorio y (ii) la determinada mediante equipos nucleares.

El primero es el método más exacto y es el que se emplea en las correlaciones y ajustes de otros procedimientos, pero tiene el inconveniente de que es un método destructivo y de resultado no inmediato. Por otra parte, los equipos de medida de densidad nucleares no proporcionan resultados del todo exactos, y su uso requiere unas medidas de seguridad y formación del operador muy específicas. Sin embargo, presenta la ventaja de proporcionar de manera rápida e inmediata la densidad del pavimento de una manera no destructiva.

A finales de los ochenta apareció en el mercado un dispositivo no nuclear denominado Indicador de Calidad del Pavimento (en adelante, PQI) que incorpora ciertas ventajas sobre los de densidad nuclear, ya que no requiere precauciones adicionales de seguridad ni una preparación específica del operador. El funcionamiento de este equipo se basa en la el establecimiento de un campo eléctrico toroidal mediante la emisión de ondas eléctricas para medir la impedancia del material que atraviesa. A partir de estos datos, el ordenador convierte las señales de campo en lecturas de densidades.

Algunas publicaciones ponen de manifiesto que la variabilidad que presenta el equipo con respecto a los datos obtenidos en testigos es similar, y en ocasiones menor, que la proporcionada por equipos nucleares $(2,3)$. Se trata de un equipo probado y aceptado por numerosos estudios para el control de calidad en mezclas asfálticas en caliente, sin embargo, de acuerdo con la bibliografía consultada, no hay información suficiente que avale su empleo en mezclas que utilizan emulsión como ligante. En las mezclas asfálticas fabricadas con emulsión existe inicialmente un elevado contenido de agua, procedente del propio ligante y del agua incorporada para la preenvuelta y compactación. Esta humedad se va perdiendo y la mezcla va adquiriendo mayor cohesión. Este proceso se conoce como curado de la emulsión. Cuando la mezcla pierde el agua, se puede proceder a la toma de testigos y medida de su densidad.

\section{INTRODUCTION}

From a structural perspective, the quality of an asphalt mix is conditioned by two factors: its design and its density (1). In road building, it is necessary to have instant density readings when a mix is being elaborated in order to be able to adjust its compactness and thus achieve optimal results. The usual methods for measuring the density of asphalt mixes are the following: (i) the laboratory measurement of pavement cores; (ii) on-site density measurement with nuclear gauges.

Since the laboratory measurement of core samples is more precise, it is generally used for correlations and fits with other procedures. However, it has the disadvantage of being a destructive method, which does not provide immediate density measurements. In contrast, nuclear gauges measure density in a non-destructive way and provide immediate pavement density readings. Nevertheless, they can only be operated by highly-trained, certified personnel and their use requires strict safety precautions.

At the end of the 1980s, a non-nuclear gauge known as the Pavement Quality Indicator (PQI) appeared on the market. It is an improvement over nuclear gauges since it is lighter and less time-consuming to operate in the field without the need for special licensing or training. The sensing plate of the gauge creates a toroidal electrical sensing field in the pavement with electrical waves. Then, a receiver on the $P Q I$ measures the impedance of the material being penetrated. Based on these data for determining the overall dielectric constant of the material, a computer transforms these signals into density readings.

According to certain authors, PQI density readings have a variability that is similar to that of the laboratory measurements of core samples. In fact, PQI variability is sometimes even lower than the variability of nuclear density gauge measurements $(2,3)$. The accuracy of the $P Q I$ has been tested and verified in research on the quality control of hot asphalt mixes. However, as reflected in the literature, a larger quantity of data is needed to definitively prove its usefulness for the density measurement of asphalt emulsion mixes. Asphalt emulsion mixes initially have a high moisture content that comes from the binder as well as the water added for pre-mixing and compaction. As the moisture gradually disappears, the mix progressively acquires greater cohesion. This process is known as emulsion curing. As the mix dries, it is then possible to extract core samples and measure their density. 
El objetivo principal de este trabajo es analizar si el equipo PQI puede ser utilizado en la determinación de las densidades in situ en mezclas fabricadas con emulsión (templadas o fabricadas en frío).

En este artículo, se presenta una descripción del equipo PQI, se analizan los resultados de estudios desarrollados por otros investigadores sobre este equipo en m.b. en caliente, y se exponen los resultados obtenidos en un proyecto de investigación en el que se ha realizado un control exhaustivo de densidades a una mezcla bituminosa fabricada con emulsión a temperaturas inferiores a $100^{\circ} \mathrm{C}$, utilizando como métodos de medida de densidad los tres métodos posibles: la densidad de testigos en laboratorio, la densidad in situ con equipo nuclear y densidad in situ con PQI.

\section{EL DISPOSITIVO INDICADOR DE CALIDAD DE PAVIMENTO (PQI)}

El Indicador de Calidad de Pavimento (PQI) es un procedimiento de medición "no nuclear" de la densidad in situ. El equipo utiliza ondas eléctricas para medir la constante dieléctrica del material. La densidad de la mezcla asfáltica es directamente proporcional a la medida de esta constante, y los dispositivos electrónicos del equipo convierten las señales de campo en interpretaciones de la densidad. El procesador de datos calcula esta densidad corregida por la humedad que pueda estar presente en el pavimento.

Este dispositivo utiliza un voltaje continuo de baja frecuencia, determinando la densidad, o nivel de compactación, por la respuesta del campo eléctrico del detector del dispositivo, a los cambios en la impedancia eléctrica de la matriz del material. Esta impedancia es una función de la constante dieléctrica del material y del aire atrapado en los huecos de la capa compactada. Debido a que la constante dieléctrica del aire es muy inferior a la del pavimento, cuando la compactación se incrementa, la constante dieléctrica combinada aumenta al disminuir el porcentaje de aire en la mezcla (4). Un estudio realizado por Romero (5) concluye que para el control de calidad en mezclas bituminosas en caliente es un método perfectamente aceptable y que, por su rapidez, constituye un procedimiento idóneo para las mediciones de densidad in situ.

\subsection{Experiencias con el equipo $P Q I$ en mezclas en caliente}

De la bibliografía estudiada sobre el empleo del equipo PQI en la determinación de densidades in situ en m.b. en caliente destacan los siguientes trabajos:
The objective of this study was to analyze whether a PQI can be used to determine the on-site density of warm or cold asphalt emulsion mixes.

This article describes the PQI gauge and analyzes the results obtained in previous research on hot asphalt mixes. It then presents the results obtained in this study, which closely monitored the densities of an asphalt emulsion mix manufactured at temperatures lower than $100{ }^{\circ} \mathrm{C}$. For this purpose, three methods were used: (i) the laboratory density measurement of pavement cores; (ii) on-site density measurement with a nuclear gauge; (iii) on-site density measurement with a PQI non-nuclear gauge.

\section{THE PAVEMENT QUALITY INDICATOR (PQI) DEVICE}

The Pavement Quality Indicator (PQI) is a non-nuclear gauge for the on-site measurement of pavement density. As previously mentioned, it uses electrical waves to measure the dielectric constant of the material. The density of the asphalt mix is directly proportional to the value of this constant. The system converts the signals into density interpretations, and the data processor then calculates this moisture-corrected density in the pavement.

The PQI uses continuous low-frequency voltage to determine the density or compaction level, based on the response of the electrical field of the device detector to the changes in the electrical impedance of the pavement matrix. This impedance is a function of the dielectric constant of the material and of the air trapped within the voids of the compacted layer. Due to the fact that the dielectric air constant is much lower than that of the pavement, when compaction increases, the combined dielectric constant also increases as the percentage of air in the mix decreases (4)]. Romero (5) found that the $P Q I$ could be used for the quality control of hot asphalt mixes. Because of its speed and effectiveness, it also can be a very useful instrument for on-site density measurements.

\subsection{Experiments with the $P Q I$ gauge on hot bituminous mixes}

There have been various research studies on the use of the PQI to measure the density of asphalt mixes. One of the most relevant is: 
Hausman et al. (6) realizan una comparación en la exactitud y reproductibilidad entre un dispositivo de medida no nuclear y otro nuclear, utilizados para la determinación de la densidad de pavimentos asfálticos compactados. Se comparó el PQI 300, con el equipo nuclear Troxler 344. Sobre la base de este estudio se determinó que el Modelo 300 de PQI de TransTech es un instrumento fiable y exacto para medir la densidad in situ de las mezclas asfálticas en caliente compactadas. También se reconoce como un instrumento sencillo y más ligero, que causa menos tensión en los técnicos, sin necesidad de una licencia para la manipulación de materiales radioactivos. Es rápido y tiene buena repetitividad y, a diferencia de los equipos nucleares, no requiere extensas y periódicas calibraciones.

En un estudio realizado por Bryan C. Smith (7) se determinan medidas de densidad por métodos nucleares y no nucleares, a partir de la información recogida de ocho proyectos de pavimentación ejecutados en el Estado de Virginia. Se llegó a la conclusión, que aplicando una corrección a los datos del PQI basada en un índice de humedad, determinado a partir de los valores obtenidos en este estudio y para las condiciones específicas del mismo, las medidas obtenidas con este equipo correlacionaban mejor con las mediciones de densidad de testigos que las medidas obtenidas con el nuclear.

Alex K. Apeagyei (8) señala que son ya numerosos los estados en EE UU que utilizan conjuntamente los equipos no nucleares in situ y la determinación de densidad en testigos como criterios de aceptación del grado de compactación.

Algunos investigadores han reconocido una correlación excelente entre las densidad de testigos y las mediciones con el equipo PQI, sin embargo, hay estudios (9) que solo lo recomiendan para su uso como control de calidad (QC) no como aseguramiento de la calidad (QA), por lo que no existe total consenso en que este nuevo equipo se pueda utilizar como herramienta de aprobación de la densidad final alcanzada en obra.

\subsection{Estudios sobre los factores que afectan la determinación de la densidad in situ}

La bibliografía pone de manifiesto que existen varios factores que influyen en la medida de la densidad determinada por el PQI como son el contenido de humedad, la temperatura, el tipo de mezcla y el espesor de la capa entre otros.

En 2002, Romero indicó que los equipos basados en impedancia eléctrica eran sensibles a la humedad y
Hausman et al. (6), who compared the accuracy and reproducibility of nuclear and non-nuclear gauge measurements to determine the density of compacted asphalt pavements. More specifically, these authors compared the PQI 300, a non-nuclear density gauge, with the Troxler 344, a nuclear gauge. This study found that pavement density measurements made with the PQI 300 (TransTech) were both accurate and reliable. The results also underlined the fact that the PQI was a lightweight instrument that was easy to use. Technicians could operate it without being certified for the manipulation of radioactive material. It is also quick and has a good level of reproducibility. Unlike nuclear devices, it does not have to be periodically calibrated.

Similarly, Smith (7) measured pavement density with nuclear and non-nuclear gauges at eight road construction projects in Virginia. After analyzing the data collected, he applied a moisture correction factor, which was calculated from the values obtained and based on the specific conditions of the study. According to the results obtained, PQI density measurements were found to be more accurate than nuclear density measurements since they showed a better correlation with core sample measurements.

In line with this Apeagyei (8) points that that many state highway authorities in the USA now use on-site non-nuclear gauges as well as core samples to measure pavement density. Used in combination, these methods are regarded as a way of measuring density as well as of calculating the degree of compaction.

Other researchers have also found an excellent correlation between the laboratory density measurements of core samples and on-site PQI measurements. Nonetheless, there are studies (9) that only recommend the PQI for quality control, and not for quality assurance. As a result, there is not a general consensus that this new type of density gauge can be used as a tool to guarantee the final density of the asphalt mix at the road construction work site.

\subsection{Studies on the factors that can affect on-site pavement density measurement}

The literature on the subject reflects the fact that there are various factors that influence PQI density measurement, such as moisture content, temperature, mix type, layer thickness, etc.

In 2002, Romero observed that gauges based on electrical impedance were sensitive to moisture and temperature. 
a la temperatura, por lo que en presencia de elevado contenido de agua los resultados obtenidos tienen que ser contrastados con otros métodos (5). Un estudio en Texas, añadió a estos dos factores, el voltaje de la batería del equipo (10). Posteriormente en Ohio se estudió la influencia de factores como la granulometría de la mezcla, la temperatura, humedad, área de la superficie de la base del equipo en contacto con la muestra y espesor de la misma en la determinación de la densidad por el equipo PQI, llegando a la conclusión que aplicando el factor de calibración definido por el fabricante se obtienen medidas fiables de densidad (11). Estudios de campo han incluido varias combinaciones de estos factores, en general se han basado en la correlación entre varios métodos de medida de densidad $(6,12)$.

El estudio de Bryan C. Smith (7) incluye el análisis de varios factores influyentes en las mediciones de densidad in situ. En estas experiencias se encontró que el efecto de la humedad en la mezcla tenía un impacto importante sobre las mediciones de densidad del equipo no nuclear.

\section{METODOLOGÍA}

Para analizar la viabilidad de utilización del dispositivo PQI en mezclas con emulsión, una vez revisada la bibliografía sobre su empleo en m.b. en caliente y los factores que afectan la determinación de la densidad in situ, la metodología de esta investigación trata de dar respuesta a las siguientes cuestiones:

a) ¿Cómo varía la densidad obtenida con el PQI con el contenido de humedad presente en la mezcla?

b) ¿Cuál es la variabilidad del equipo PQI, en las medidas de densidad un situ, cuando se emplea en una mezcla fabricada con emulsión?

c) ¿Es el dispositivo adecuado para valorar la evolución de la densidad in situ en mezclas fabricadas con emulsión?

Enmarcado en el proyecto de investigación: "Utilización de mezclas bituminosas templadas con emulsión en firmes de carreteras" (13) se ha desarrollado el control de densidades de una mezcla bituminosa templada mediante los tres procedimientos existentes de medida de densidad de mezclas asfálticas; densidad de testigos en laboratorio (NLT 168/90), densidad in situ utilizando equipo nuclear (Troxler 3440) y densidad in situ con equipo no nuclear (PQI 301).

Se ha dividido la carretera objeto de estudio en 7 tramos en función de su fecha de ejecución. En cada tramo se midió la densidad con el PQI en sucesivos hitos temporales, comprobando la pérdida de humedad con el
For this reason, when the material had a high moisture content, the results obtained had to be verified with other methods (5). A study in Texas even added the voltage of the density gauge battery to the previous two factors (10). Subsequently, research carried out in Ohio studied whether PQI density measurements were influenced by factors such as aggregate grain-size, temperature, moisture, surface area and thickness of the base of the gauge in contact with the pavement layer. The authors concluded that by applying the calibration factor defined by the manufacturer, it was possible to obtain reliable density measurements (11). Field studies include various combinations of these factors, and, generally speaking, are based on the correlation between various methods for measuring pavement density $(6,12)$.

Smith (7) analyzed various factors that influence on-site density measurements, and found that the effect of moisture on the asphalt mix had an important impact on the density readings of the non-nuclear gauge.

\section{METHODOLOGY}

This study on the use of the PQI gauge for the density measurement of asphalt emulsion mixes has the following objectives:

a) To find out how PQI density measurements vary with the moisture content in the mix.

b) To calculate the variability of the PQI gauge when it is used to measure the density of asphalt emulsion mixes.

c) To ascertain if the PQI is suitable to evaluate the evolution of the on-site density of asphalt emulsion mixes.

Within the context of the research project, "The use of warm bituminous mixes with emulsion in road surfaces" (13), the densities of a warm bituminous mix were monitored with the following three methods: (i) the laboratory density measurement of pavement cores (NLT 168/90); (ii) on-site density testing with a nuclear moisture-density gauge (Troxler 3440); (iii) on-site density testing with a non-nuclear gauge (PQI 301).

The road surface tested in this study was divided into seven sections, depending on when the road surface had been constructed. The density of each section was measured with the PQI at successive time intervals. The 
paso del tiempo. Estas mediciones se realizaron desde su extensión hasta el momento en que fue posible la extracción de testigos del pavimento sin que se produjera la desintegración de la muestra. En la Tabla 1 se muestran el número total de mediciones de PQI de cada tramo estudiado. purpose was to verify the progressive moisture loss over a period of time. The measurements were performed from the time when the pavement was spread until it was possible to extract cores without any risk of the samples disintegrating. Table 1 shows the total number of PQI measurements taken of each road section.

Tabla 1 / Table 1

Medidas de PQI.

$P Q I$ measurements.

\begin{tabular}{|c|c|c|}
\hline Tramo / Section & Long. total / Total Length $(\boldsymbol{m})$ & $\mathbf{N}^{\mathbf{0}}$ Med. PQI / $\mathbf{N}^{\mathbf{~}}$ of PQI Measurements \\
\hline T1 & 550 & 61 \\
\hline T2 & 1000 & 64 \\
\hline T3 & 1000 & 33 \\
\hline T4 & 1200 & 33 \\
\hline T5 & 1400 & 45 \\
\hline T6 & 1200 & 40 \\
\hline T7 & 1300 & 33 \\
\hline
\end{tabular}

Los trabajos de investigación desarrollados se dividen en las siguientes etapas:

a) En una primera fase, partiendo de las 61 mediciones in-situ efectuadas con PQI en el tramo 1 , se estudia la relación entre las densidades y las variables humedad y temperatura. Para evaluar estas relaciones se recurre a una regresión lineal simple, en la que la variable dependiente siempre es la densidad, y, la variable independiente es en el primer caso la humedad y en el segundo la temperatura. El objetivo es comprobar cuál de las variables (humedad y temperatura) influye más en la medida de densidad obtenida con este dispositivo.

b) Para analizar en laboratorio la variación de la densidad medida con el PQI como consecuencia de las variaciones en el porcentaje de humedad de la muestra, una vez que la mezcla ha perdido toda su humedad se extraen 3 muestras (probetas paralelepípedas cortadas en seco) procedentes de tres puntos distintos de la obra.

Las 3 probetas se sumergen en agua durante 24 horas con el fin de saturarlas y posteriormente se someten a un proceso de reducción de la humedad mediante secado en estufa. Se registran las medidas de la densidad y humedad tomadas con el PQI y la humedad real de la mezcla.

c) Por último se analizan las diferencias obtenidas en las medidas de densidades con los tres métodos de estudio. Estas medidas, se efectúan en el momento en el que se pudieron extraer los testigos del pavimento, es decir, cuando la mezcla perdió toda su humedad. En la Tabla 2 se indican el número de mediciones realizadas en los distintos tramos de la obra y sobre las que se ha desarrollado esta parte del estudio.
The research was performed in the following stages:

a) Stage 1: The relation between the density values and those for moisture and temperature were studied, based on 61 on-site measurements made with the $P Q I$ in section 1 of the road surface. These relations were evaluated with a simple linear regression in which the dependent variable was always density. In the first case, the independent variable was moisture and in the second case, it was temperature. The objective was to verify which of these variables (humidity or temperature) most influenced the density value obtained with this gauge.

b) Stage 2: In order to conduct a laboratory analysis of the variation of $P Q I$-density measurements as a result of progressive moisture loss, three parallelepiped core samples were extracted from the dry pavement at three different locations of the work site. The three cores were submerged in water for 24 hours in order to saturate them.

The moisture was subsequently eliminated by ovendrying the specimens. The density and moisture readings obtained with the $P Q I$ and the values of the real moisture of the asphalt mix were then recorded.

c) Stage 3: Finally, the differences in the density values obtained with the three methods were analyzed. These measurements were taken when the pavement was sufficiently dry to extract core samples, in other words, when the mix had lost all of its moisture. Table 2 shows the number of measurements performed in the different road sections, and which were used during this stage of our research study. 
Tabla 2 / Table 2

Medidas de densidad con los tres métodos.

Density measurements with the three methods.

\begin{tabular}{|c|c|c|c|}
\hline Tramo / Section & $\begin{array}{c}\mathbf{N}^{\circ} \text { mediciones PQI I } \\
\mathbf{N}^{\circ} \text { of PQI Measurements }\end{array}$ & $\begin{array}{c}\mathbf{N} \text { mediciones nuclear } / \\
\mathbf{N}^{\circ} \text { of nuclear measurements }\end{array}$ & $\begin{array}{c}\mathbf{N}^{\circ} \text { testigos extraídos / } \\
\mathbf{N}^{\circ} \text { of samples extracted }\end{array}$ \\
\hline T1 & 18 & 18 & 18 \\
\hline T2 & 20 & 20 & 20 \\
\hline T3 & 12 & 12 & 12 \\
\hline T4 & 13 & 13 & 13 \\
\hline T5 & 10 & 10 & 10 \\
\hline T6 & 15 & 15 & 26 \\
\hline T7 & 26 & 26 & 114 \\
\hline
\end{tabular}

Se comprueba que la distribución de frecuencias, en lo que se refiere a las densidades se ajuste a una distribución normal en los tres casos para poder comparar los resultados obtenidos.

\section{ANÁLISIS DE RESULTADOS}

A continuación se analizan los resultados obtenidos en las diferentes etapas de la investigación.

\subsection{Fase 1. Relación entre los valores de densidad obtenidos con PQI y las variables humedad y temperatura}

En la Figura 1 ( $\mathrm{a}$ y b) aparecen correlaciones entre la densidad y la humedad y temperatura registrados por el equipo PQI en el tramo 1 . Se puede apreciar que al disminuir el contenido de humedad con el paso del tiempo disminuye la densidad. Se observa una mejor relación entre las variables densidad-humedad que entre densidad-temperatura.

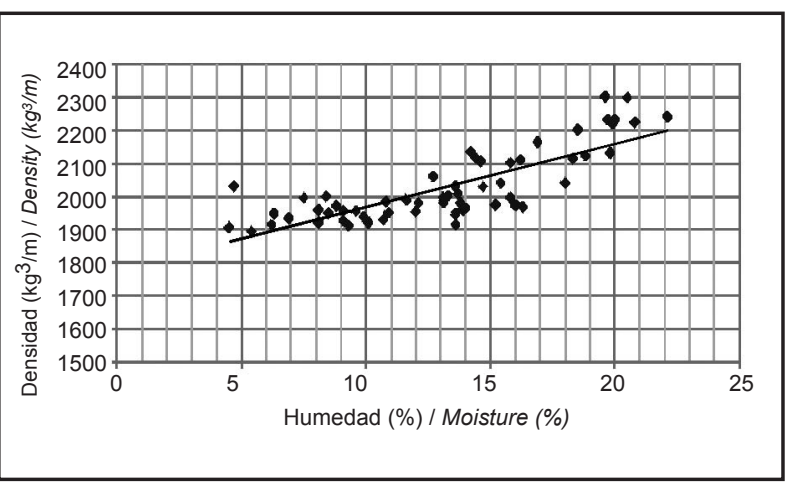

Figura 1a. Correlación entre densidad y humedad. Figure 1a. Correlation between pavement density and moisture.
It was observed that the frequency distribution of the densities fit a log-normal distribution in all three cases, which facilitated the results comparison.

\section{DISCUSSION OF RESULTS}

The following sections analyze and discuss the results obtained in the three phases of our research study.

\subsection{Stage 1. Relation between the PQI density values and the moisture and temperature variables}

Figures $1 a$ and $1 b$ show the correlations between the density measurements and the humidity and temperature values recorded with the PQI gauge in road section 1. The graphs show that as the moisture content decreases over time, the pavement density decreases. $A$ closer relation was observed between the density-moisture variables than between the density-temperature variables.

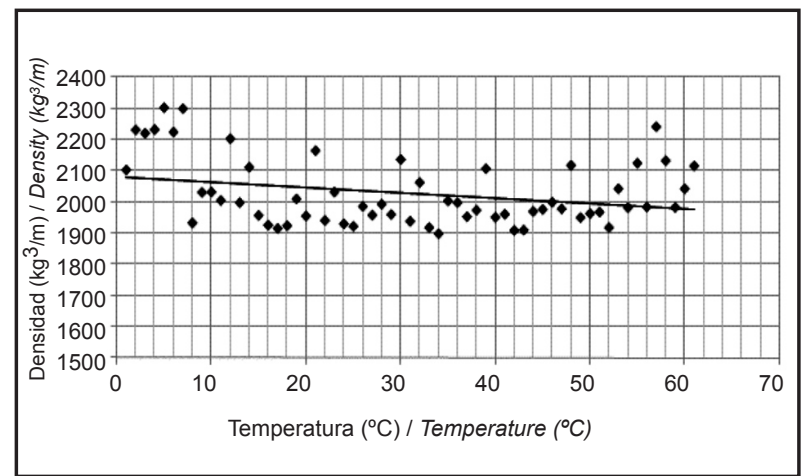

Figura 1b. Correlación entre densidad y temperatura. Figure 1b. Correlation between pavement density and temperature 
La siguiente ecuación proporciona el modelo lineal que describe la relación entre densidad y humedad [1]:
The following equation gives the linear model that describes the relation between pavement density and moisture [1]:

$$
\text { Density }=1780.843+18.915 * \text { humidity }
$$

Como el P-valor (0) en la tabla ANOVA es menor de 0,05 , existe una relación estadísticamente significativa entre Densidad y Humedad con un nivel de confianza del 95\%. El estadístico R-Cuadrado indica que el modelo ajustado explica el 66,0\% de la variabilidad en Densidad. El coeficiente de correlación es igual a 0,813 , indicando una relación fuerte entre las variables.

Los valores de los indicadores estadísticos obtenidos al realizar el mismo estudio entre los valores de densidad y temperatura (Coeficiente de correlación $=0,061$ ) indicaron que entre estas dos variables no existe correlación.

\subsection{Fase 2. Variación de la densidad obtenida en laboratorio provocada por la variación del contenido de humedad de la mezcla}

Tras comprobar en el apartado anterior cómo disminuye la densidad medida con el PQI conforme disminuye el contenido en agua en las mediciones realizadas en obra, se estudia esta situación en el laboratorio.

Como se ha descrito en la metodología las 3 probetas paralelepípedas se saturaron y se sometieron a un proceso de secado forzoso en estufa, registrándose las medidas de densidad y humedad del PQI.

La Figura 2 representa la densidad medida con el dispositivo $\mathrm{PQI}$ en cada momento. Obsérvese cómo la densidad se reduce a medida que aumenta el tiempo en estufa, es decir, a medida que se reduce su contenido de humedad.
Since the $p$-value $(0)$ in the ANOVA table is less than 0.05 , there is a statistically significant relation between density and moisture with a 95\% confidence level. The $R$-square statistic indicates that the model explains $66.0 \%$ of the density variability. The correlation coefficient is equal to 0.813 , which indicates a close relation between variables.

The values of the statistical indicators obtained for density and temperature values (correlation coefficient $=0.061$ ) reflect that there is no correlation between these two variables.

\subsection{Stage 2. Laboratory density variation caused by variation of the moisture content of the mix}

The results obtained in the previous stage showed that on-site PQI pavement density measurements decreased as the water content decreased. In the second stage, this same phenomenon was studied in laboratory conditions.

As previously mentioned, for this purpose, three parallelepiped test specimens were submerged in water and afterwards oven-dried. Density and moisture values were then obtained with the PQI.

Figure 2 shows the density measured with the PQI gauge at each moment. As can be observed, the density decreased in accordance with the length of time that the test specimen remained in the oven. In other words, the density of the test specimen decreased as its moisture content decreased.

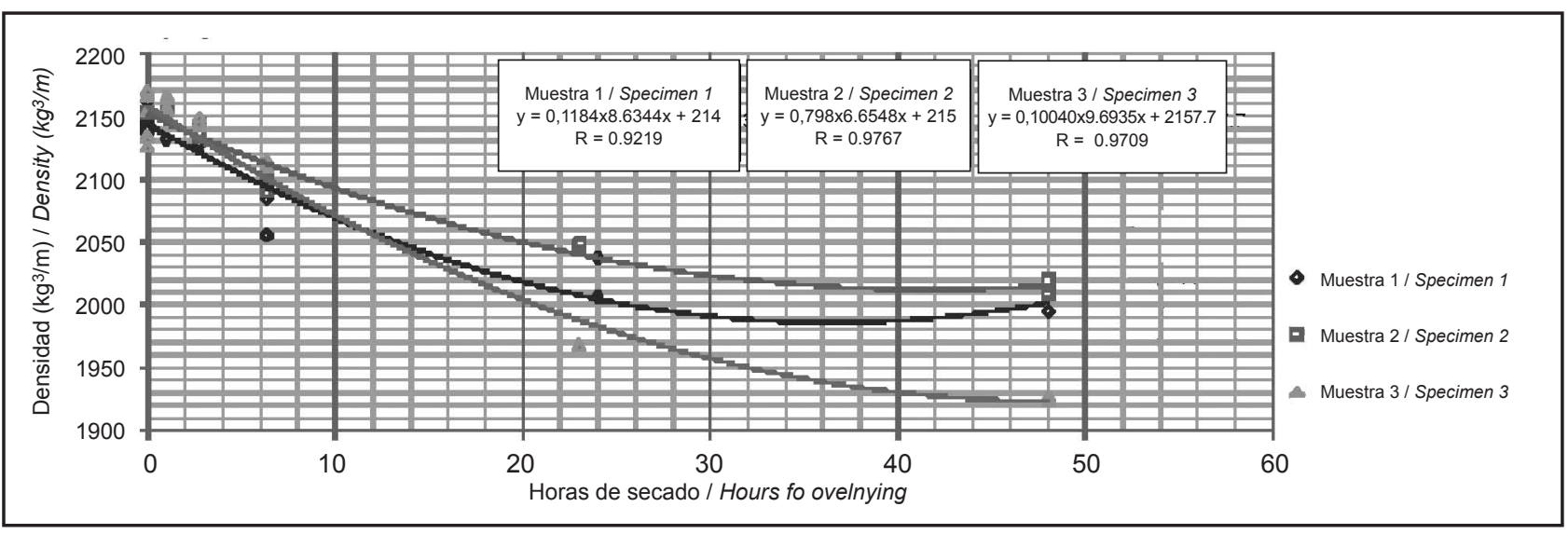

Figura 2. Variación de la densidad en laboratorio medida con el PQI en muestras secadas en estufa.

Figure 2. Density variation of oven-dried test specimen samples, measured in the laboratory with a PQI gauge. 
En la Figura 3 se ha representado, para la muestra 1, la densidad respecto al contenido de humedad, y se observa una buena dependencia. Durante la prueba se observó que los valores de humedad que proporciona el equipo son mucho más elevados que los porcentajes reales de humedad en la mezcla, sin embargo, tal y como se puede comprobar en la Figura 4, existe una relación directa entre ambos valores.

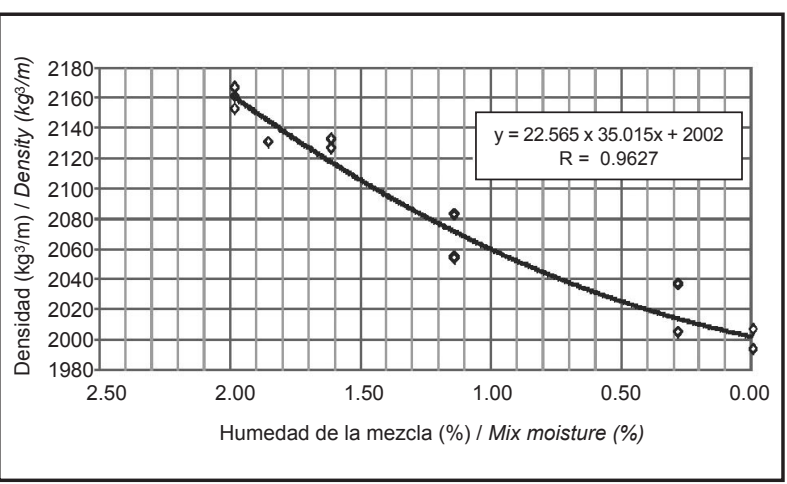

Figura 3. Variación de la densidad con el contenido de la humedad en la mezcla.

Figure 3. Density variation, depending on the moisture content of the mix.

Por tanto para este caso concreto de estudio, se ha determinado la correlación existente entre la humedad medida por el PQI y la humedad real de la mezcla.

\subsection{Fase 3. Comparación entre las densidades in situ obtenidas con el quipo nuclear, PQI y medida de densidades de testigos en laboratorio}

En las figuras 5-7 se observa que la distribución de frecuencias para los tres casos se ajusta bastante bien a una ley normal.
Figure 3 depicts the density in regards to the moisture content of the specimen sample. There is clear dependence between the two variables. During the experiment, it was observed that the moisture values provided by the gauge were much higher than the actual moisture percentages in the mix. Nevertheless, as shown in Figure 4 , there is a close relation between both values.

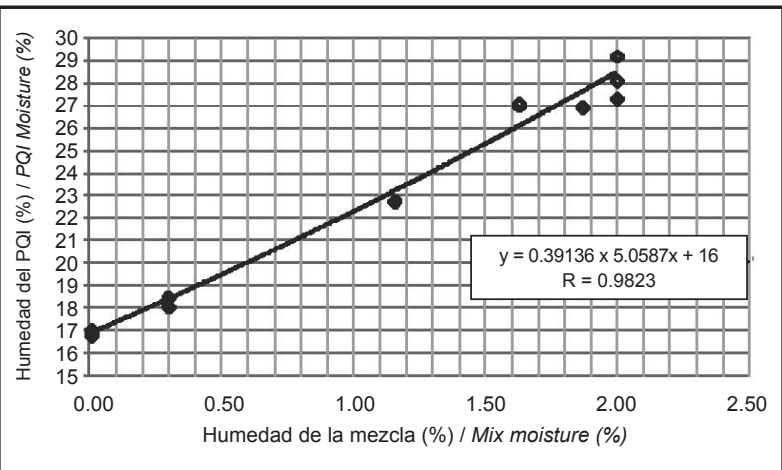

Figura 4. Relación entre la humedad medida con el PQI y la humedad real.

Figure 4. Relation between PQI moisture measurements and the actual moisture content of the core sample.

Consequently, in this case, our study found a correlation between the PQI moisture readings and the real moisture of the mix.

\subsection{Stage 3. Comparison between on-site nuclear density measurements, on-site PQI density measurements, and laboratory density measurements of core samples}

Figures 5-7 show the frequency distribution of core sample density measurements, nuclear density measurements, and non-nuclear density measurements. As can be observed, they fit a log-normal distribution.
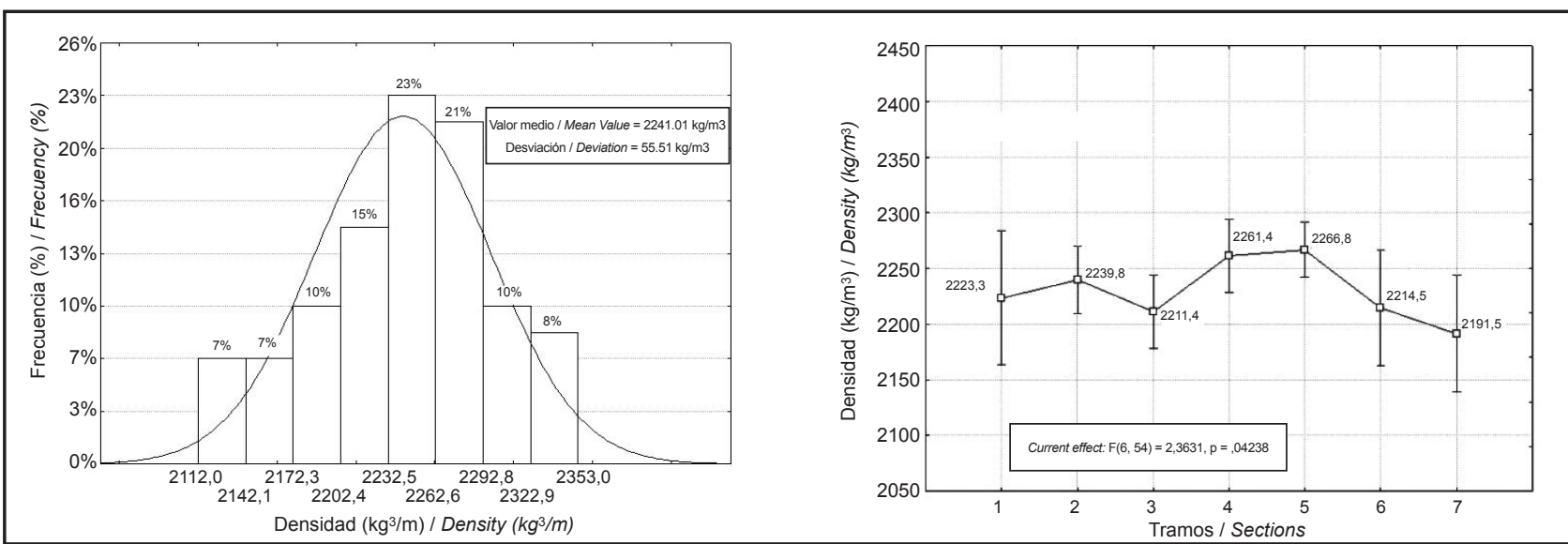

Figura 5. Distribución de frecuencias y valores medios densidades testigos por tramos.

Figure 5. Frequency distribution and mean density values of core samples from different road sections. 

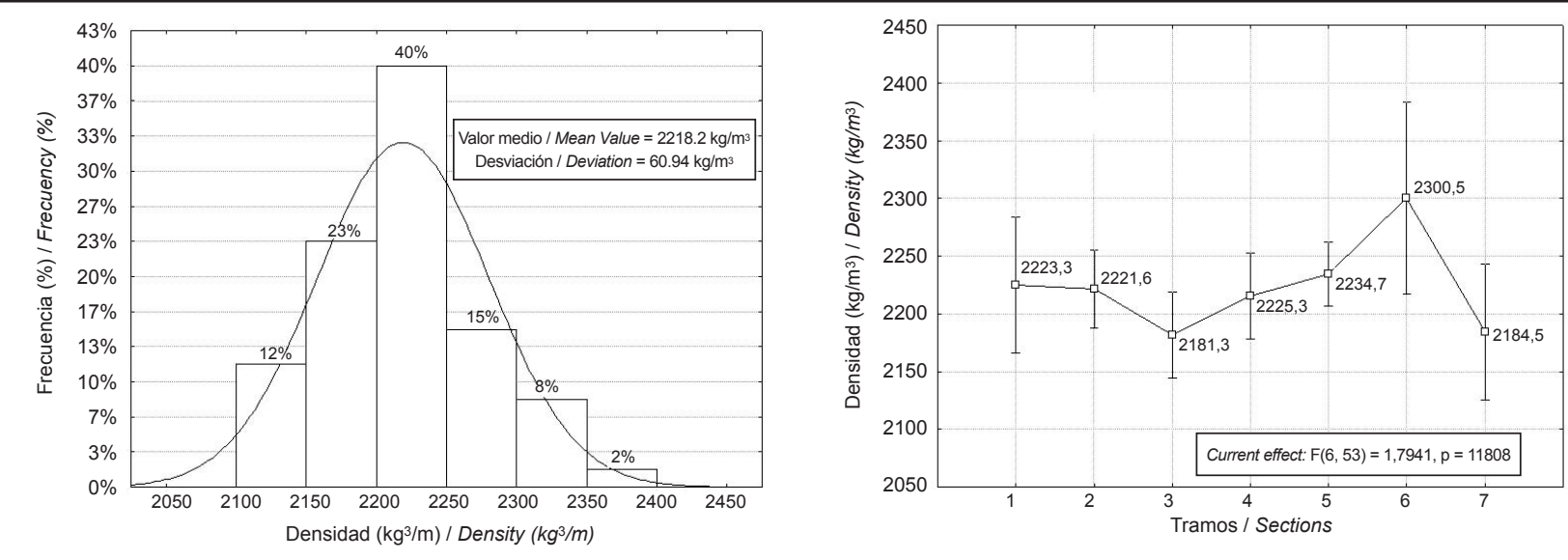

Figura 6. Distribución de frecuencias y valores medios densidades nuclear por tramos.

Figure 6. Frequency distribution and nuclear mean density values at different road sections.
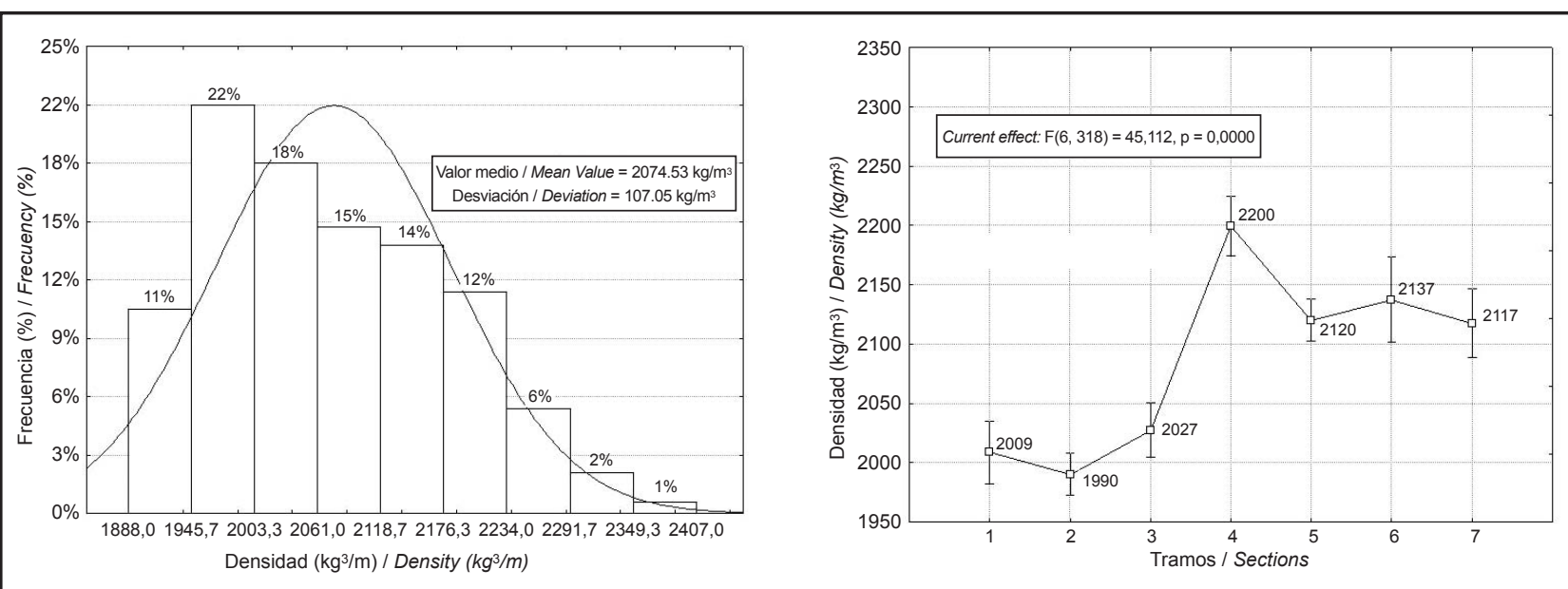

Figura 7. Distribución de frecuencias y valores medios densidades PQI por tramos.

Figure 7. Frequency distribution and PQI mean density values at different road sections

Para todas las variables nos encontramos ante una ley de distribución normal y con unos intervalos de confianza para una probabilidad del $95 \%$ similares, lo que permite comparar los valores medios de densidades por los tres métodos de medida objeto de estudio.

La Figura 8 muestra las densidades medias de cada tramo obtenidas por cada uno de los métodos analizados. Se observa que las medidas obtenidas con el equipo nuclear son ligeramente inferiores a las obtenidas sobre testigos en laboratorio, mientras que las determinadas con el equipo PQI son más bajas respecto a los otros dos métodos, especialmente en los tres primeros tramos.

En las Figuras 9 y 10 se representan mediante gráficas de dispersión las relaciones entre las densidades determinadas en testigos en laboratorio y las densidades obtenidas in situ con el equipo nuclear y el PQI. Se han
All of the variables had a log-normal distribution and a 95\% confidence interval. This made it possible to compare the mean density values for the three methods.

Figure 8 shows the mean densities in each road section for each of the methods studied. The measurements obtained with the nuclear gauge were found to be slightly lower than those of the laboratory test specimens. In contrast, the values obtained with the PQI gauge were lower compared to those obtained with the other two methods, especially in the first three road sections.

The scatter plots in Figures 9 and 10 show the relations between the densities determined in the laboratory with the test specimens and the densities obtained on-site with the nuclear gauge and the non-nuclear PQI gauge. 


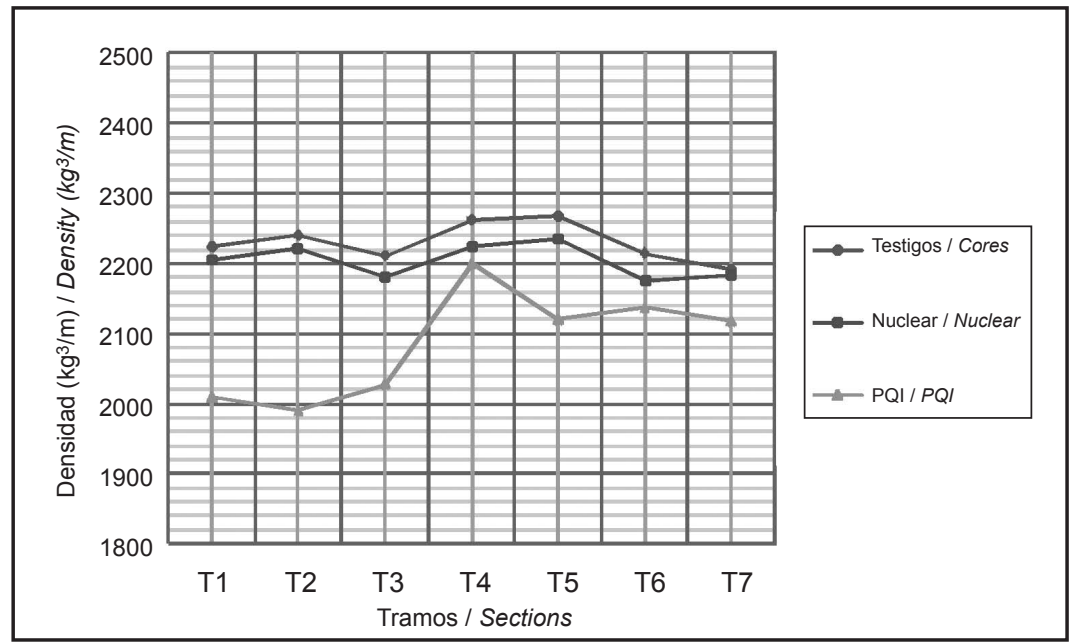

Figura 8. Densidades medias tres procedimientos.

Figure 8. Mean densities obtained with the three methods.

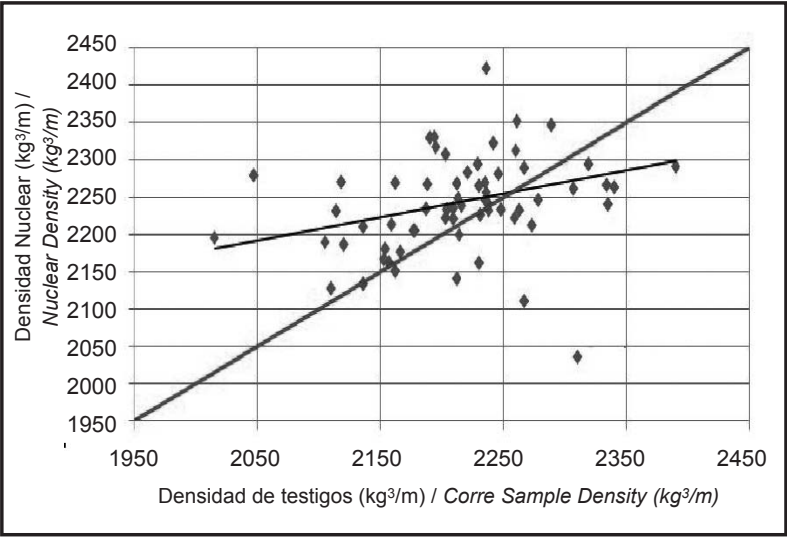

Figura 9. Densidades testigos / Densidades Nuclear.

Figure 9. Densities of cores samples / Nuclear densities.

señalado en dichas gráficas las líneas de equidistancia y se observa que los puntos de las medidas realizadas con el PQI se encuentran todos por debajo de dicha línea, es decir, todos los valores de densidad obtenidos con el PQI son inferiores a los obtenidos en testigos. Las medidas realizadas con el nuclear no siguen ninguna tendencia definida, en algunos casos son mayores y en otras menores.

\section{CONCLUSIONES}

A partir de las experiencias obtenidas con este trabajo se puede decir que el dispositivo PQI puede ser utilizado, en mezclas templadas con emulsiones, con el propósito de comprobar el grado de maduración y realizar el seguimiento de la evolución de las mezclas, pero no existe suficiente información para recomendarlo como una herramienta fiable para el control de calidad y determinación de la densidad. Las mediciones de densidad in situ deben hacerse de forma continuada en el tiempo para controlar

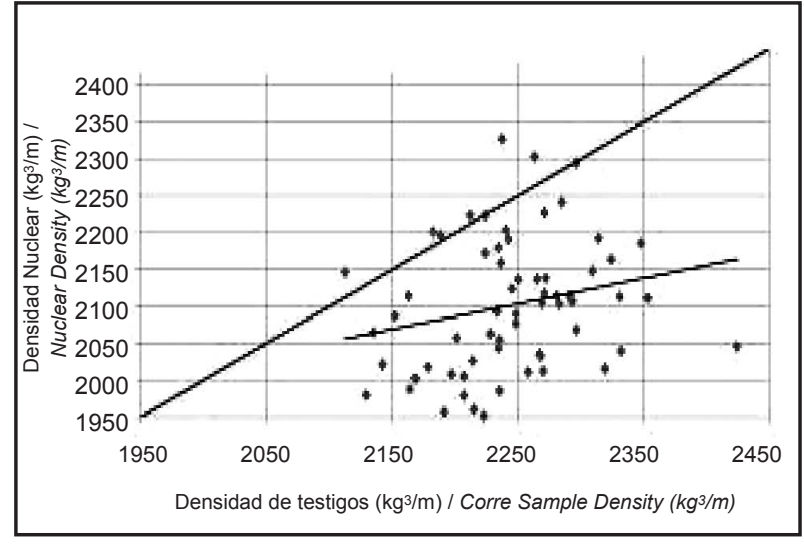

Figura 10. Densidades testigos / Densidades PQI. Figure 10. Densities of core samples / PQI densities.

These scatter plots show the lines of best fit. As can be observed, the PQI measurement dots are all below this line. In other words, all of the PQI density values are all lower than those obtained with the test specimens. The measurements obtained with the nuclear gauge do not follow any definite tendency. In some cases, they are higher and in other cases, lower.

\section{CONCLUSIONS}

The results of this research study show that the PQI gauge can be used to test the maturity of warm asphalt mixes as well as to monitor their evolution. However, there is still not enough data to recommend this device as a reliable instrument for quality control and for determining pavement density. 
la pérdida de humedad, hasta el momento en que se puedan extraer testigos.

Se ha comprobado que la influencia que tiene la humedad en la medida de la densidad con el PQI es muy elevada. $Y$ que el valor que el equipo refleja del contenido de humedad en la muestra no es real, aunque para los datos de este estudio, sí existe una correlación directa entre la humedad real y la humedad medida por el PQI, por lo que se puede definir un coeficiente de corrección para determinar la humedad real. La temperatura, sin embargo, no es un factor que afecte a la medida de la densidad.

El equipo PQI muestra ventajas en la determinación de las densidades in situ que lo hacen más adecuado que los equipos de densidad nucleares, por lo cual sería conveniente un estudio más profundo para poder determinar factores de corrección en los valores de humedad, de manera que pueda ser utilizado para el control de la mezcla fabricada con emulsión, con la misma confianza con la que se puede emplear en mezclas en caliente para control de calidad.
On-site measurements should be performed continuously in order to monitor moisture loss until the moment when it is possible to extract core samples.

The study described in this paper verified that moisture strongly influences PQI pavement density measurements. Furthermore, it was found that the PQI moisture readings did not correspond to the actual moisture content of the core samples. However, the data this study reflected a direct correlation between actual moisture content and PQI moisture measurements, which made it possible to define a correction coefficient in order to calculate the real moisture content with this gauge. The temperature, however, did not affect PQI density measurements.

The PQI gauge has advantages for the on-site measurement of pavement density, which makes it more suitable and easier to use than nuclear density gauges. Accordingly, a more in-depth study would be advisable with a view to determining correction factors for the moisture values. In this way, the PQI could be more effectively used for the quality control of asphalt emulsion mixes with the same reliability as for hot asphalt mixes.

\section{BIBLIOGRAFÍA / BIBLIOGRAPHY}

(1) Huges, C.: "NCHRP Synthesis of Highway Practice 152: Compaction of Asphalt Pavement". TRB, National Research Council. Washington, D.C. (1989).

(2) Prowell, B.; Dudley, M.: "Evaluation of measurement techniques for asphalt pavement density and permeability". Transportation Research Record, vol. 1789. Paper No 02-3907 (2002), pp. 36-45.

(3) Williams, S.: "Non-nuclear methods for HMA density measurements". Mack-Blackwell Transportation Center: Research and Special Programs Administration. No 2075 (2008), final report.

(4) Trans Tech Systems: Pavement Quiality Indicator. Model 301. Operator`s Handbook.

(5) Romero, P.: "Evaluation of non-nuclear gauges to measure density of hot-mix asphalt pavements". Pool Fund Study. Departament of Civil and Environmental Engineering. The University of Utah (2002).

(6) Hausman, J. J.;Buttler, W. G.: "Analylis of Trans Tech Model 300. Pavement Quality Indicator: Laboratory and field studies for determining asphalt pavement density". Transportation Research Record, vol.1813. Paper No 02-4055 (2002), pp. 191-200.

(7) Smith, B.; Diefenderfer, B.: "Comparison of nuclear and non nuclear pavement density testing devices", Transportation Research Board. Annual Meeting (2008).

(8) Apeagyei, A.; Diefenderfer, B.; Clark, T.: "Density measurement methods for acceptance of bituminous mixtures: a survey of practice", Transportation Research Board. Annual Meeting (2010).

(9) Practicó, F.; Moro, A.: "In-lab and on-site measurements of hot mix asphalt density: convergence and divergence hypotheses", Constr. Build. Mater., vol.25 (2011), pp. 1065-1071. DOI: 10.1016/j.conbuildmat.2010.06.071.

(10) Sebesta, S.; Zeig, M.; Scullion, T.: "Evaluation of non-nuclear density gauges for HMAC" Report FHWA/TX-04/0-4577-1. Texas Transportation Institute, Texas. A-M University System, College Station (2003).

(11) Sargand, S.; Kim, S.; Farrington, S.: "A working review of available non-nuclear equipment for determining in-place density of asphalt", Final Report for State Job 147960. Ohio Research Institute for Transportation and the Enviroment, Columbus (2005). (12) Rao, C.; Von Quintus, H.; Schmitt, R.: "Calibration of non-nuclear density gauge data for accurate in-place density prediction", Transportation Research Board. Annual Meeting (2007).

(13) Research Project No GGI-1029/IDIO. Utilización de mezclas bituminosas templadas con emulsión en firmes de carreteras. Laboratorio de Ingeniería de la Construcción. Universidad de Granada, Agencia de Obra Pública de la Junta de Andalucía, General de Estudios y Proyectos, S.L. Spain (2010). www.aopandalucia.es/principal.asp?alias=inv_bituminosas\&zona=innovacion\&t=0 Accessed (14/11/2011). 